\title{
Let's put standardisation in practice: accessibility services and interaction
}

\author{
ESTELLA ONCINS \\ estella.oncins@uab.cat \\ Universitat Autònoma de Barcelona \\ PILAR ORERO \\ pilar.orero@uab.cat \\ Universitat Autònoma de Barcelona
}

Fecha de recepción: 15 de julio de 2020

Fecha de aceptación: 20 de octubre de 2020

Abstract: Quality is a subjective attribute. For media accessibility, quality is an agreed benchmark issued by a standardisation agency. The context of work on media accessibility in standardisation agencies is the Convention on the Rights of Persons with Disabilities (CRPD), wherein article 9.2 requests States Parties to take appropriate measures, among others "To develop, promulgate and monitor the implementation of minimum standards and guidelines for the accessibility of facilities and services open or provided to the public". Meeting CRPD requirements has led to many international standardisation agencies to actively produce technical requirements towards accessibility, both for physical and digital/online environments. Technology is developing at a fast pace to produce new interactions, which turn into new communication barriers, some of which might be avoidable. Looking at recommendations from some accessibility standards at the design stage could solve many issues and help towards native accessible technology. This article looks at existing standards related to accessibility and media communication. The first part of the article looks at different standardisation agencies and the need to produce harmonised standards for accessibility at IEC, ITU, ISO and W3C. The second part of the article outlines how standards are produced and implemented at a European level by the European Standardisation Organisations (CEN, CENELEC and ETSI). It then lists existing standards for each media accessibility service: subtitling, audio description, audio subtitling and sign language. Mention is made of Easy to Read as a new emerging accessibility modality. The final part of the article will provide conclusions and directions for further research.

Keywords: Media Accessibility, Standards, Accessibility services, Subtitling, Audio description, Audio subtitling, Easy to Read. 
Resumen: La calidad es un atributo subjetivo y, en el caso de la accesibilidad a los medios, es un acuerdo de recomendaciones consensuado en las agencias de estandarización. El artículo 9.2 de la Convención de los derechos de las personas con discapacidad (CRPD) recoge: los Estados Partes tomarán las medidas apropiadas para desarrollar, diseminar y monitorizar la implementación de unos mínimos en estándares y guías de buenas prácticas para lugares y servicios abiertos o suministrados al público. El CRPD es el contexto de trabajo de las agencias internacionales de estandarización para producir los requisitos técnicos para la accesibilidad, tanto para entornos físicos como digitales. La tecnología se está desarrollando a gran velocidad para permitir nuevas interacciones del usuario con el entorno, que a la vez se convierten en nuevas barreras de comunicación, algunas evitables. Tener en cuenta los estándares de accesibilidad en la fase inicial del diseño y desarrollo ayudaría a que la tecnología fuera accesible desde un inicio. Este artículo analiza los estándares existentes relacionados con la accesibilidad y la comunicación a los medios. La primera parte del artículo revisa la importancia de redactar estándares armonizados para la accesibilidad en cuatro agencias que producen estándares de accesibilidad: IEC, ITU, ISO y W3C. Luego describe cómo las organizaciones europeas de normalización (CEN, CENELEC y ETSI) producen e implementan estándares. En la segunda parte del artículo se presentan los servicios de accesibilidad a los medios: subtitulado para personas sordas, audiodescripción para personas con discapacidad visual, audiosubtitulado y lengua de señas. También se menciona la lectura fácil como una nueva modalidad de accesibilidad emergente. En la parte final del artículo se proporcionan conclusiones y direcciones para futuras investigaciones.

Palabras clave: Accesibilidad Media, Estándares, Servicios de accesibilidad, Subtitulado para personas sordas, Audiodescripción para personas con discapacidad visual.

\section{INTRODUCTION}

Accessibility has been associated to two basic concepts when analysing person-environment relationships: usability and Universal Design (Iwarsson and Ståhl 2003). The built environment and transport were the two starting fields for accessibility research, where most theoretical discussions took place towards the end of the last century (Sanford 2012). Accessibility, then and even today, is closely linked to disability and the possibility of rehabilitation (Lid 2009). This means applying a clinical model for user classification to areas where there is no scope for remedial health action. Reading subtitles will never restore hearing, listening to audio description will never improve sight. Accessibility requirements are usually classified 
according to the United Nations World Health Organization Disability Assessment Schedule (WHODAS). This document classifies people's impairments for clinical rehabilitation, even when dealing with the Social Construction of Disability in New Media (Goggin and Newell 2003). Some voices have been raised to distinguish between "impairment effects and disabling barriers" (Lid 2014: 1344) and the possibility of moving from disabilities to Amartya Sen's model of capabilities (Mitra 2006, 2018). This represents a departure from disability and accessibility towards usability and diversity pointing towards normalisation (Ellis 2016, Orero and Tor-Carrogio 2018, Agulló et al. 2019). For some academics, Universal Design (UD) is no longer a rehabilitation inclusive concept, but a proactive design production following the seven principles of User Design (UD)-which are in fact good for all members of society (Molly Follette Story 1998). These days, accessibility is moving away from exclusive approaches towards a democratic participative society looking for diversity and inclusion (Taylor 2017). This accessibility state of the art is also reflected in standardisation, where, for example, the Spanish UN media accessibility standards have the rights and exclusive approach to Subtitles for the Deaf (UNE 153010:2012) Audio Description for the Blind (UNE 153020:2005).

\section{HOW DO STANDARDS COME INTO EXISTENCE?}

Standards are consensus documents developed by committees which are made up of various stakeholders such as: experts from the industry, public and consumer interest groups, and government representatives with an interest in a particular topic. By following recommendations gathered in a standard, quality might be achieved. Understanding how standards are produced and the importance of contributing with research data towards quality benchmarking is the objective of this article. Documents go through various stages of development, and at all times there is the need for researchdriven data and expert participation.

According to the EU Regulation (EU) No 1025/2012:

The primary objective of standardisation is the definition of voluntary technical or quality specifications with which current or future products, production processes or services may comply. Standardisation can cover various issues, such as standardisation of different grades or sizes of a particular product or technical specifications in product or services markets where compatibility and interoperability with other products or systems are essential.

International standards provide rules, guidelines or characteristics for activities or for their results, and aim at achieving the optimum degree of order, 
i.e. quality, in a given context. There are formal and informal standards. Formal standards are documents that are elaborated, approved or adopted by national, (i.e. AENOR in Spain), regional (i.e. CEN, CENELEC and ETSI in Europe), or international standards bodies (i.e. ISO, IEC and ITU), whilst informal standards are published by other standards development organisations (SDOs), many of which are very well known and respected, (i.e W3C).

Standards fall into two main categories, normative and informative. Normative documents contain requirements which must be met for compliance with the standard to be certified. Conversely, informative documents do not contain any requirements, hence certification of compliance cannot be claimed. It should be mentioned that, while most standards are normative, they also include informative elements in the form of notes, examples, and annexes. Still, some standard documents are purely informative. These are usually published as technical specifications, technical reports, test methods, codes of practice, guidelines, and management systems. ISO, for example, releases three levels of documents: (a) international standards (IS), the highest-level normative documents requiring approval by the national standardisation bodies; (b) technical specifications (TS), intermediate-level normative documents that must be reviewed three years after their publication; and (c) technical reports (TR), which do not have a normative status, but rather are informative documents. Other standardisation bodies make a similar distinction between informative, guidance, and normative documents.

National and international bodies define a standard as a document providing rules and guidelines which is established by agreement among all interested stakeholders. In the following section, the join coordination work of the main international standardisation agencies in the media accessibility field is explained. Then, we will outline how harmonised standards are first elaborated at a European level by the European standardisation organisations (CEN, CENELEC and ETSI) and then applied at a national level by the national standardisation bodies of the EU Member States.

\subsection{Standardisation agencies}

There are many names to describe an organisation working with standards: Standards Organisation (SO), Standards Body (SB), Standards Development Organisation (SDO), or Standards Setting Organisation (SSO). All these organisations develop technical standards which are voluntary. Exceptionally, some standards become mandatory when they are adopted by regulators as legal requirements in particular domains. A good example is the WCAG 2.0 (W3C), quoted in the European Union's Web Accessibility 
Directive (2016). Standardisation agencies may be at international, regional, or national levels. Their business is to organise standards, draft new ones, and revise existing ones which are then sold.

\subsection{International standardisation agencies}

There are four main agencies for accessibility at a global level: The International Electrotechnical Commission (IEC), the International Organization for Standardization (ISO), The United Nations agency for International Telecommunication Union (ITU), and the World Wide Web Consortium (W3C). The W3C, created in 1994 by Lee Burnes-Jones, is an international community developing open standards to ensure resilience in the long-term growth of the web. W3C is the leading standards body for the web industry. Their Web Content Accessibility Guidelines (WCAG 2.0, now WCAG 2.1), published in 2008, were adopted by ISO as ISO/IEC 40500:2012. Therefore, countries will be able to make reference to this standard in their national legislation, thus improving harmonisation in terms of legislation on web accessibility between different countries.

The traditional IEC, ISO and ITU comprise the World Standards Cooperation (WSC) alliance, which was established in 2001. Their objective is to create international standards that bring technological, economic, and societal benefits. The WSC also promotes the adoption and implementation of international consensus-based standards worldwide. It helps to harmonise technical and other product and services specifications, making industry more efficient and breaking down barriers for international trade. Conformity to International Standards helps reassure consumers that products are safe, efficient, and good for the environment. According to Matamala and Orero (2019: 144), "ISO and IEC have established a Joint Technical Committee 1: ISO/IEC JTC 1. This committee has responsibility for standardisation in the area of information technology. Within JTC 1 are a number of technical committees of which Subcommittee 35 (SC 35) is the lead subcommittee on User Interface Component accessibility. ISO/IEC JTC 1/SC 35 have now joined ITU IRG-AVA and will, in the future, endorse joint international standards on accessibility".

To ensure that standards contribute to accessibility, IEC, ISO, and ITU elaborated a joint policy statement on standardisation and accessibility, emphasising the importance of the following four points:

1) Apply the principles of Accessible Design or Universal Design

2) Engage older persons and persons with disabilities in the development of standards 
3) Train standards developers on the importance of accessibility

4) Improve accessibility of standardisation secretariat support

Moreover, to support the need to address accessibility in international standards, in 2001 ISO and IEC published the ISO/IEC Guide 71 - Guide for addressing accessibility in standards, which was adopted by ITU as ITU-T Supplement 17 for the $\mathrm{H}$-series, to support the mainstreaming of accessibility features into standards. For European standardisation activities, CEN and CENELEC adopted this standard as CEN/CENELEC "Guide 6 - Guidelines for standards developers to address the needs of older persons and persons with disabilities" (CEN/CENELEC 2002).

\subsection{Regional Level: European Standardisation Organisations (ESO)}

CEN, CENELEC and ETSI are the regional mirror bodies to their international counterparts, i.e. ISO, IEC and ITU-T respectively. In the European Union, only standards developed by CEN, CENELEC and ETSI are recognised as European Standards. Hence, CENELEC closely cooperates with CEN and ETSI, working jointly in the interest of European harmonisation, creating both standards requested by the market and harmonised standards in support of European legislation (EU Directives). According to the EU Regulation (EU) No 1025/2012, "'harmonised standard' means a European standard adopted on the basis of a request made by the Commission for the application of Union harmonisation legislation". An example is the harmonised European standard EN 301549 Accessibility requirements suitable for public procurement of ICT products and services in Europe, which was the result of a standardisation mandate, called Mandate ${ }^{1} 376$, sent by the European Commission to the European Standardisation Organisations (CEN, CENELEC and ETSI). This mandate aims to assist with the harmonisation of public procurement practices in Europe by developing a standard that specifies the functional accessibility requirements for public procurement of ICT products and services.

With the finalisation of the Web Accessibility Directive (2016), it was necessary to update EN 301 549. In 2017, the European Commission produced standardisation request Mandate 554. This required CEN, CENELEC and ETSI to update EN 301549 so that it could be adopted as a harmonised standard. The importance of the standard EN 301549 v2.1.2

${ }^{1}$ Mandates are the mechanism by which the European Commission (EC) and the secretariat of the European Free Trade Association (EFTA) request the European Standardisation Organisations (ESOs) to develop and adopt European standards in support of European policies and legislation. 
(2018) resides in that being endorsed by law is now mandatory in all EU Member States. At the moment, it only affects public sector organisations, but it is expected that, shortly, other sectors outside the public sphere will need to comply with the EU legislation and provide accessible websites.

\subsection{National standardisation agencies}

Each country has its own national standards body (NSB). There are two workflows to generate a standard. The national standards body may prepare its own standards which are then sent to one of the three international agencies to be reworked as international standards. A good example is the Spanish Easy to Read (UNE/PNE153101 EX) standard, which is becoming an international ISO standard ISO/IEC 23859:2019(X) Information technology - User interfaces - Guidance on making written text easy to read and easy to understand.

It may work the other way round: a standard is developed at international level and is then localised and adopted by a national standardisation agency. Some national agencies are OFCOM in the UK, AFNOR in France, UNI in Italy and DIN in Germany.

\section{HARMONISED STANDARDS ADDRESSING ACCESSIBILITY}

In recent years, the EU has published a number of laws that address digital accessibility and promote digital inclusion, such as the Web Accessibility Directive (2016), which establishes common accessibility requirements for all Member States enabling everyone to read, understand, and complete administrative procedures on public sector websites and mobile applications. The second law is the Audiovisual Media Services Directive (2018), which covers the means to achieve accessibility such as with sign language, subtitling for the Deaf and Hard-of-Hearing and audio descriptions for both television broadcasting (i.e. linear services) and video on demand (VOD). The last law passed is the European Accessibility Act (2019), which sets common accessibility requirements, including a number of key ICT products and services.

Harmonised standards, such as the EN 301 549, mean that all EU Member States now have common requirements for digital accessibility in the public sector. Where national legislation on accessibility exists, the laws need to be harmonised with the existing directives. An example is Germany, a country with an existing national accessibility law, Behindertengleichstellungsgesetz (BGG), which supports some WCAG 2.1 level AAA requirements that are not in the Web Accessibility Directive. Therefore, regulation needs to refer to EN 301549 and additionally to the supported WCAG level AAA requirements. In other countries, there is no 
legislation on digital accessibility in place, thus new legislation needs to be written. One of the main problems of harmonisation in the EU is that some national digital accessibility requirements differ in terms of coverage (to what and to whom they apply), on the level of detail, and on the technical details themselves (Oncins et al. 2020). An example is the subtitling service. All public broadcasters in the EU provide subtitles, but this service is not covered on all platforms. Only in a few countries, media authorities required subtitles on online platforms or there were voluntary agreements to provide subtitles on all platforms.

In order to address these differences in coverage, the European Accessibility Act (EAA) aims to help dismantle barriers between European countries due to different national digital accessibility requirements that are emerging. The EAA establishes functional requirements for all European countries. This means requirements establishing accessibility principles instead of prescribing the detailed technical solutions. The EAA will tell "what" needs to be accessible in terms of functional requirements but will not impose detailed technical solutions telling "how" to make it accessible. Still, while accessibility requirements have become mandatory in the European legislative frameworks of the Member States, the relevant EU law does not define what accessibility means and what it entails, leaving this to be defined in national or sector-specific standards.

\section{STANDARDS BY ACCESSIBILITY SERVICES}

Accessibility is defined within EN ISO 9241-112:2017 as the "extent to which products, systems, services, environments and facilities can be used by people from a population with the widest range of user needs, characteristics and capabilities to achieve identified goals in identified contexts of use". However, there is no common international definition on how products and services should be made accessible. International standardisation agencies provide guidance to regional and national standardisation bodies to develop legislations, such as the AVMSD. These laws include accessibility requirements with reference to standards for certain products or services to meet user needs and comply with obligations, such as EN 301 549. Still, key stakeholders in the media accessibility industry are confused by the different types of standards issued at international, regional, and national level, as well as their applicability. The table below compares two different types of standards documents issued at regional (EN 301549 ) and international level (ISO/IEC and ITU). 


\begin{tabular}{|c|c|c|c|}
\hline $\begin{array}{l}\text { Definition/S } \\
\text { tandard }\end{array}$ & $\begin{array}{lcl}\text { EN } & 301 & 549 \\
(\text { WCAG 2.1) }\end{array}$ & ISO/IEC & ITU \\
\hline Applicability & $\begin{array}{l}\text { Public entities, } \\
\text { limited to the EU. } \\
\text { Regional } \\
\text { normative } \\
\text { standard. }\end{array}$ & $\begin{array}{l}\text { Commercial use. } \\
\text { International } \\
\text { informative } \\
\text { standards: } \\
\text { Technical } \\
\text { specifications } \\
\text { and guidelines. }\end{array}$ & $\begin{array}{l}\text { Non-commercial } \\
\text { use. International } \\
\text { informative } \\
\text { standards: Technic } \\
\text { al reports, } \\
\text { guidelines, checklist } \\
\text { and toolkit. }\end{array}$ \\
\hline Scope & $\begin{array}{l}\text { Regulate and } \\
\text { provide } \\
\text { accessibility } \\
\text { requirements for } \\
\text { ICT products and } \\
\text { services. }\end{array}$ & $\begin{array}{l}\text { Provide } \\
\text { guidance to } \\
\text { accessibility } \\
\text { services. Focus } \\
\text { on how to create } \\
\text { and deliver the } \\
\text { service. }\end{array}$ & $\begin{array}{l}\text { Provide guidance to } \\
\text { accessibility } \\
\text { services. Focus on } \\
\text { technical papers. }\end{array}$ \\
\hline Compliance & $\begin{array}{l}\text { EU Standard } \\
\text { refers to WCAG } \\
2.1 \text { guidelines } \\
\text { which set three } \\
\text { levels (A, AA, } \\
\text { AAA), testable } \\
\text { success criteria for } \\
\text { each accessibility } \\
\text { service. }\end{array}$ & $\begin{array}{l}\text { Do not provide } \\
\text { compliance } \\
\text { levels. } \\
\text { Guidelines and } \\
\text { checklists are } \\
\text { intended to } \\
\text { guide companies } \\
\text { and r } \\
\text { organisations. }\end{array}$ & $\begin{array}{l}\text { Do not provide } \\
\text { compliance. } \\
\text { Guidelines and } \\
\text { checklists } \\
\text { intended to guide } \\
\text { companies and } \\
\text { organisations. }\end{array}$ \\
\hline Availability & Free to access. & $\begin{array}{l}\text { It has a cost and } \\
\text { a purchase } \\
\text { process. }\end{array}$ & Free to access. \\
\hline Coverage & $\begin{array}{l}\text { Same standard } \\
\text { covers all } \\
\text { accessibility } \\
\text { services, based on } \\
\text { WCAG } 2.1 \text {. }\end{array}$ & $\begin{array}{l}\text { Different } \\
\text { informative } \\
\text { standards for } \\
\text { each } \\
\text { accessibility } \\
\text { service including } \\
\text { different modes, }\end{array}$ & $\begin{array}{l}\text { Different informative } \\
\text { standards, i.e. } \\
\text { recommendations, } \\
\text { covers different } \\
\text { accessibility } \\
\text { services depending } \\
\text { on the mode, i.e. }\end{array}$ \\
\hline
\end{tabular}

Hikma 20 (1) (2021), 71 - 90 


\begin{tabular}{|l|l|l|l|}
\hline & $\begin{array}{l}\text { i.e. live or pre- } \\
\text { recorded. }\end{array}$ & $\begin{array}{l}\text { live or pre- } \\
\text { recorded. }\end{array}$ \\
\hline
\end{tabular}

Table 1 - Comparison between EN 301 549, ISO/IEC and ITU accessibility standards

With the entry into force of the Web Accessibility Directive (2016), the updated Audiovisual Media Services Directive (2018), and the European Accessibility Act (2019), national standardisation agencies from each Member State are adapting their laws in order to ensure access and availability of the requested media accessibility services according to European legislation, namely sign language, subtitling for the deaf and hard of hearing, spoken subtitles, and audio description.

\subsection{Subtitling}

Subtitling/captioning is the most covered media accessibility service in international, regional, and national standardisation agencies and laws. ISO, ITU/IEC and W3C mention three common elements related to subtitles/captions, which are: primary audience (people who are Deaf and Hard of Hearing), service eligibility (closed or open subtitles/captions) and time-based (live, semi-live or pre-recorded subtitles).

ITU documents related to accessibility services are non-commercial documents and mainly informative, namely delivered in the form of technical papers, guidelines, and checklists. Their main scope is to ensure that the specified accessibility services and features are usable by a wide range of users including people with disabilities. The ITU documents related to subtitling are:

2019 - FSTP-ACC-RCS - Overview of remote captioning services. This technical paper describes remote captioning services. It defines reference models, requirements and functionalities that facilitate, via an assistive intermediary (i.e. real time captioner or via voice recognition software), to enable the inclusive meeting participation of people either on site or remotely.

2016 - FSTP-UMAA - Use cases for assisting persons with disabilities using mobile applications. This technical paper is based on use cases and presents some applications on smartphones that can facilitate some of daily life tasks for people with disabilities.

2015 - FSTP-AM - Guidelines for accessible meetings. This technical paper provides guidelines for the organisation of meetings that facilitate the inclusion of persons with disabilities (including age-related ones) and the elimination of barriers for participation. 
2015 - FSTP-ACC-RemPart - Guidelines for supporting remote participation in meetings for all. These guidelines outline the requirements for ensuring that meetings are accessible to remote participants, including those with disabilities and those using assistive technologies.

2006 - FSTP-TACL - Telecommunications Accessibility Checklist. This document intends to ensure that the specified services and features are usable by a wide range of users, including people with disabilities.

ISO documents covering the subtitling service are for commercial use and subject to purchase. ISO has two documents related to subtitling, namely ISO/IEC 20071-23:2018 Information technology - User interface component accessibility - Part 23: Visual presentation of audio information (including captions and subtitles) and ISO/IEC TS 20071-25:2018 Information technology - User interface component accessibility — Part 25: Guidance on the audio presentation of text in videos, including captions, subtitles and other on-screen text. Both documents are informative standards and apply to all presentations of visual alternatives to audio information intended to be presented as captions/subtitles and aim at improving accessibility (Matamala \& Orero 2019). While the 20071-23 are guidelines with a focus on the creation and delivery process, the second, 20071-25, are technical specifications related to quality, user involvement and visual design.

In the EU, requirements for subtitling services are covered in the normative standard EN 301 549, which directly references WCAG 2.1 guidelines from W3C. These guidelines are divided into the following four principles: 1) perceivable, meaning that information and user interface components must be presentable to users in ways they can perceive. 2) operable, meaning that user interface components and navigation must be operable. 3) understandable, meaning that information and the operation of the user interface must be understandable. 4) robust, meaning that content must be robust enough to be interpreted reliably by a wide variety of user agents, including assistive technologies. Each principle is made up of Accessibility Guidelines (a total of 13 guidelines). For each Accessibility Guideline there are one or more testable success criteria which are classified into three levels ( $A, A A, A A A)$.

Subtitling requirements are addressed in success criterion 1.2.2 (captioning for recorded media) and 1.2.4 (captioning for live media). According to Success Criterion 1.2.2 Captions (Pre-recorded), captions are provided for all pre-recorded audio content in synchronised media, except when the media is a media alternative for text and is clearly labelled as such. (Level A). According to Success Criterion 1.2.4 Captions (Live), captions are provided for all live audio content in synchronised media. (Level AA). 


\subsection{Audio Description}

In the last decades, audio description (AD) has increased in popularity in media accessibility research, practice, and standards. Still, different studies have stressed the importance of creating a European AD standard (Orero 2005, Vercauteren 2007). AD is an accessibility service that has been practiced and studied all over the world, with different countries following different timeframes in terms of enforcement of legislation, provision of $A D$ services, production of guidelines, as well as support for research and training initiatives, such as ADLAB 2012 or ADLAB PRO 2017. In 2008, Spain was the only country in the world with a written standard for audio description, namely the AENOR Spanish technical standards, Standard UNE 153020:2005: Requirements for audio description (Puigdomènech et al. 2008).

At an international level, different standardisation documents have been elaborated, with the main focus on providing guidance for the creation and delivery of the AD service. This is the case of ITU - International toolkit on providing, delivering and campaigning for audio description on television and film (ITU-D) (2011, updated in 2016) and FSTP-CONF-F921 - Compliance of audio-based navigation system for persons with vision impairment (2018). The first document is a toolkit with a main focus on sharing information on the development of $A D$ across countries and providing support and technical information to key stakeholders working to improve media accessibility. The second is a technical paper which provides a conformance framework for testing that implementations of audio-based network navigation systems are accessible for persons with vision impairments.

In the EU, requirements for the audio description service are covered in the normative standard EN 301 549, which directly references WCAG 2.1 guidelines from W3C. Audio description requirements are addressed in three Success Criteria. The first is Success Criterion 1.2.5 Audio Description (Prerecorded) (Level AA). Audio description is provided for all pre-recorded video content in synchronised media. The second is Success Criterion 1.2.3 Audio Description or Media Alternative (Pre-recorded) (Level A). An alternative for time-based media or audio description of the pre-recorded video content is provided for synchronised media, except when the media is a media alternative for text and is clearly labelled as such. The third is Success Criterion 1.2.7 Extended Audio Description (Pre-recorded) (Level AA). Where pauses in foreground audio are insufficient to allow audio descriptions to convey the sense of the video, extended audio description is provided for all pre-recorded video content in synchronised media. For Success Criteria 1.2.3, 1.2.5, and 1.2.7, if all of the information in the video track is already provided in the audio track, no audio description is necessary. 


\subsection{Audio Subtitling}

Audio subtitling is not a widespread accessibility service. Few references to audio subtitling in standards can be found and "[i]n most cases written subtitles appear in the 'What to describe?' section in AD standards and guidelines". (Iturregui-Gallardo 2019 42). According to ITU, most European countries do not offer this service. It is only offered in Nordic countries and in the Belgian Flanders region, where broadcasters offer all or almost all foreign programmes with audio subtitles, and not with AD (Orero et al. 2020a).

In international standards, the only mention to this service is made by ISO/IEC TS 20071-25:2017 - Information technology - User interface component accessibility - Part 25: Guidance on the audio presentation of text in videos, including captions, subtitles and other on-screen text. W3C does not cover this service and the standard EN 301549 refers to the ISO standard document.

\subsection{Sign Language}

Sign Language presentation on TV screens has been developed at Spanish level with the UNE 139804:2007 Guidance on the use of the Spanish Sign Language on computer networks. This has now been adopted by ISO/IEC/ITU SC35 towards a new Sign Language 20071-24 Information technology - User interface component accessibility - Part 24: Guidance on Sign Language on Television Screens.

In the EU, requirements for sign language services are covered in the normative standard EN 301 549, which directly references WCAG 2.1 guidelines from W3C. Sign Language requirements are addressed in one Success Criterion, which is 1.2.6 Sign Language (Pre-recorded) (Level AAA). Sign language interpretation is provided for all pre-recorded audio content in synchronised media.

\subsection{Easy-to-Read}

Easy-to-Read (E2R) is becoming a modality in Media Accessibility (Bernabé and Orero 2019). According to the authors (2019: 56), "E2R can be described for Media Accessibility as a service to improve reading and foster comprehension". At an international level, some standard documents are being issued, such as the ISO standard SO/IEC 23859:2019(X) Information technology - User interfaces - Guidance on making written text easy to read and easy to understand. There is no agreement to the term, and that has led to another ISO standard ISO/WD 24495-1 Plain language - Part 1: Governing principles and guidelines (Orero et al. 2020b). 
In the EU, requirements for E2R are covered in the normative standard EN 301549 under accessible documentation. In WCAG 2.1, there are six Success Criteria that address accessibility for people with cognitive disabilities. Some are more specific for cognitive accessibility and others can also be beneficial for other user profiles, such as people with low vision. First, Success Criterion 1.3.5 Identify Input Purpose (Level AA) states that the content must be included in a form that is clearly identifiable. Second, Success Criterion 1.3.6 Identify Purpose (Level AAA) establishes that the objective of all user interface components, icons, etc. must be clearly identified. Third, Success Criterion 1.4.12 Text Spacing (Level AA) establishes the text style properties of texts that benefit users with low vision, but also people with cognitive disabilities who need the texts to be arranged in a way that makes them easier to read. Fourth, Success Criterion 2.2.6 Timeouts (Level AAA) states that users must be informed about the time they have before the information is lost or the session ends (unless the duration is longer than 20 hours). Fifth, Success Criterion 2.3.3 Animation from Interactions (Level AAA), indicates that, in interactions with animations, the animation can be deactivated unless the functionality or the information that it conveys is essential. Last, Success Criterion 4.1.3 Status Messages (Level AA), indicates that error messages or other messages that appear on the screen must be perceived by users. This criterion benefits different types of users (people with cognitive disabilities, blind people, or people with low vision) who often miss the warning messages because of the subtle way they are displayed. The recently updated WCAG 2.1 is an intermediate step towards WCAG 3.0, which is currently under development. In the upcoming version, new accessibility criteria adapted to emerging technologies such as the Internet of things, artificial intelligence and immersivity will be considered.

\section{CONCLUSION}

The time lapse from passing a law and its implementation is around three years. In the case of Europe, laws need to be transposed to each country. This year will see the start of the legal impact on media accessibility across Europe with the Web Accessibility Directive (2016). And it is a matter of time for the other two to start impacting: the Audiovisual Media Service Directive (updated in 2018) and the European Accessibility Act (2019). To aid this transposition, the harmonised European standard EN 301549 (2018) is now in place -though it is being revised.

Much work is required towards the assessment and implementation of digital accessibility. Still, rather than focusing on reporting implementation and results, the concept of native accessible makes more sense (Oncins and Orero 2020; Oncins et al. 2013). That is, to add accessibility in the DNA of any development from conception. In the case of media production, it is what 
Romero-Fresco (2013) coined as "accessible filmmaking". By adopting this approach, industry, organisations, and governments may ensure substantial benefits beyond those of media accessibility policy or standard compliance.

With normative and informative standards being present at an early stage of media development, designers, developers, and content creators are aware of the guidelines accompanying a specific service or even the technical specifications that maintain quality for end-users. Media accessibility services thus comply with regional and national laws. Still, more training is required to support and incorporate media accessibility principles into work practices. Within this regard, educational projects such as ACT (2017), ADLAB (2012) and ADLAB PRO (Perego 2017) and existing ones such as ILSA, EASIT, LTA and IMPACT are proving to be effective in training new accessibility professionals in different fields.

The right to access media content is applicable or usable only if access is granted. Access to a medium is achieved through the provision of appropriate technology and ensuring that it is barrier free. Access to environments means providing barrier-free settings, such as assisting viewers with vision loss to reach the service. The European Regulators Group for Audiovisual Media Services (ERGA) emphasised the need to address the entire supply chain for accessibility in the television field (broadcast content, carriers such as cable TV companies, consumer equipment such as set top boxes, remote controls, TV receivers, etc.), as well as a full range of recently available content access and delivery modes.

There is still a clear gap between the legislations designed to improve digital accessibility and their practical implementation due to the high degree of technical skills required to conformance test accessibility, the costs involved in such a process, effective resourcing to address this issue, and a lack of awareness as to how people with disabilities are likely to engage with such content. As an example, subtitling is the most covered accessibility service in the public broadcasting industry, reaching $100 \%$ of the programmes in some countries. Still, there are two main challenges that broadcasters face, namely technological issues arising from the multi-platform environment and the variety of standards applied across Europe. Broadcasters often use different technologies and file formats, and apply different standards depending on the delivery platform. This is not helping the European Digital Single Market.

Whilst this paper has only been able to address accessibility services issues in standards in the broadest sense, the authors feel that accessibility is primarily impacted by social drivers, not industry, and include limited awareness as being one of the major challenges to properly address universal accessibility and acceptability. 


\section{ACKNOWLEDGEMENTS}

This work has been partially funded by ERASMUS+ IMPACT 2019-1FR01-KA204-062381, ERASMUS+ LTA 2018-1-DE01-KA203-004218, ERASMUS+ EASIT 2018-1-ES01-KA203-05275. Also by H202: MEDIAVERSE GA 957252, HELIOS GA 825585, SO-CLOSE GA 870939, TRACTION GA 870610. The authors are members of TransMedia Catalonia, an SGR research group funded by Secretaria d'Universitats i Recerca del Departament d'Empresa i Coneixement de la Generalitat de Catalunya (2017SGR113).

\section{REFERENCES}

AENOR (2018). UNE 153101: 2018 EX Lectura Fácil. Pautas y recomendaciones para la elaboración de documentos. Retrieved from: https://www.une.org/encuentra-tu-norma/busca-tunorma/norma?c=N0060036

- (2012). UNE 153010: 2012 Subtitulado para personas sordas y personas con discapacidad auditiva. Retrieved from: https://www.une.org/encuentra-tu-norma/busca-tunorma/norma/?c=N0049426

- (2007). UNE 139804:2007 Requisitos para el uso de la Lengua de Signos Española en redes informáticas. Retrieved from: https://www.une.org/encuentra-tu-norma/busca-tunorma/norma?c=N0040404

- (2005). UNE 153020:2005 Audiodescripción para personas con discapacidad visual. Retrieved from: https://www.une.org/encuentra-tunorma/busca-tu-norma/norma?c=N0032787

Agulló, B., Matamala, A., and Orero, P. (2019). From Disabilities to Capabilities: testing subtitles in immersive environments with end users. HIKMA 17, 195-220.

Bernabé Caro, R. and Orero, P. (2019). Easy to Read as Multimode Accessibility Service.Hermēneus. Revista de Traducción e Interpretación 21, 53-74.

ETSI (2015). ETSI Drafting Rules. Retrieved from: https://portal.etsi.org/Portals/0/TBpages/edithelp/Docs/38_directives_f eb_2018_part2\%20(EDRs).pdf.

ETSI/CEN/CENELEC (2018). EN 301549. Accessibility requirements suitable for public procurement of ICT products and services in Europe. Retrieved 
from: https://www.etsi.org/deliver/etsi_en/301500_301599/301549/02. 01.02_60/en_301549v020102p.pdf

European Commission (EC) (2019). European Accessibility Act. Retrieved from: https://eur-lex.europa.eu/legalcontent/EN/TXT/PDF/?uri=CELEX:32019L0882\&from=ES

European Commission (EC) (2018). Audiovisual Media Services Directive (AVMSD). Retrieved from: https://eur-lex.europa.eu/legalcontent/EN/TXT/?uri=LEGISSUM\%3Aam0005

- (2018). Digital Single Market: updated audiovisual rules. Retrieved from: http://europa.eu/rapid/press-release_MEMO-18-4093_en.htm

- (2012). European Union Regulation 1025/ 2012 on European Standardization. Retrieved from: https://eur-lex.europa.eu/legalcontent/EN/TXT/?uri=celex\%3A32012R1025

Ellis, Gerry (2016). Impairment and Disability: Challenging Concepts of "Normality". In: A. Matamala and P. Orero (Eds.), Researching Audio Description. London: Palgrave Macmillan, 35-45.

Goggin, G. M. and Newell, C.J. (2003). Digital Disability: The Social Construction of Disability in New Media. Lanham/Maryland, USA: Rowman \& Littlefield Publishers.

IEC/ISO/ITU (2014). Joint Policy Statement on Standardization and Accessibility. Retrieved from: https://www.worldstandardscooperation.org/accessibility.

ISO/IEC (2004). JTC 1 Special Working Group on Accessibility. Retrieved from: http://www.jtc1access.org/

IEC (2010). TR 62678: Audio, video, and multimedia systems and equipment activities and considerations related to accessibility and usability. Retrieved from: https://www.iec.ch/webstore/freepubs/iec62678\%7Bed1.0\%7Den.pdf

ISO (n.d.). Standards in action. Geneva, Switzerland: ISO. Retrieved from: https://www.iso.org/standards-in-action.html

- (2018). ISO/IEC DIS 20071-23: 2018 Information technology - User interface component accessibility - Part 23: Guidance on the visual presentation of audio information (including captions and subtitles).

- (2017). ISO/IEC TS 20071-25:2017 Information technology - User interface component accessibility. Part 25: Guidance on the audio 
presentation of text in videos, including captions, subtitles and other onscreen text.

- (2016a). ISO Code of Conduct for technical work. Geneva, Switzerland: ISO. Retrieved from: https://www.iso.org/files/live/sites/isoorg/files/publications/en/pub1003 97.pdf

- (2016b). My ISO job. Geneva, Switzerland: ISO. Retrieved from: https://www.iso.org/files/live/sites/isoorg/files/archive/pdf/en/my_iso_jo b.pdf

ISO/IEC (2015). TS 20071-21:2015 Information technology - User interface component accessibility - Part 21: Guidance on audio descriptions. Retrieved from: https://www.iso.org/standard/63061.html

ITU-T (2019). FSTP-ACC-RCS Overview of remote captioning services. Retrieved from: https://www.itu.int/pub/T-TUT-FSTP-2019ACC.RCS/es

- (2016). FSTP-UMAA - Use cases for assisting persons with disabilities using mobile applications. Retrieved from: https://www.itu.int/pub/TTUT-FSTP-2016-UMAA/es

- (2015). FSTP-AM - Guidelines for accessible meetings. Retrieved from: https://www.itu.int/es/publications/ITU-

T/pages/publications.aspx?parent=T-TUT-FSTP-2015-

AM\&media=electronic

- (2015). FSTP-ACC-RemPart - Guidelines for supporting remote participation in meetings for all. Retrieved from: https://www.itu.int/dms_pub/itu-t/opb/tut/T-TUT-FSTP-2015-ACCPDF-E.pdf

- (2006). FSTP-TACL - Telecommunications Accessibility Checklist. Retrieved from: https://www.itu.int/en/publications/Pages/publications.aspx?lang=en\& media=electronic\&parent=T-TUT-FSTP-2006-TACL

ITU (2011). Making television accessible. Geneva, Switzerland: ITU. Retrieved from: http://staging.itu.int/en/ITU-D/DigitalInclusion/Persons-with-

Disabilities/Documents/Making_TV_Accessible-English.pdf

ITU-T (2016). Use cases for assisting persons with disabilities using mobile applications. Geneva, Switzerland: ITU. Retrieved from: 
https://www.itu.int/dms_pub/itu-t/opb/tut/T-TUT-FSTP-2016-UMAAPDF-E.pdf

- (2015). Guidelines for supporting remote participation in meetings for all. Geneva, Switzerland: ITU. Retrieved from: https://www.itu.int/dms_pub/itu-t/opb/tut/T-TUT-FSTP-2015-ACCPDF-E.pdf

- (2006). FSTP-TACL Telecommunications Accessibility Checklist. Technical Paper. Geneva, Switzerland: ITU. Retrieved from:

https://www.itu.int/en/publications/Pages/publications.aspx?lang=en\&media= electronic\&parent=T-TUT-FSTP-2006-TACL

Iwarsson, S. and Ståhl, A. (2003). Accessibility, usability and universal designpositioning and definition of concepts describing person-environment relationships. Disability and Rehabilitation, 25(2), 57-66.

Lid, I. M. (2009). What can be achieved by universal design? An investigation of various aspects of the concept. FORMakademisk 2009 (17), 17-27.

- (2014). Universal Design and disability: an interdisciplinary perspective. Disability and Rehabilitation 36 (16), 1344-1349.

Matamala, A. and Orero, P. (2013). Standardising audio description. Italian Journal of Special Education for Inclusion, 1, 149-155.

- (2018) Standardising accessibility: transferring knowledge to society. Journal of Audiovisual Translation 1 (1), 139-154.

Mitra, S. (2006). The Capability Approach and Disability. Journal of Disability Policy Studies 16(4), 236-247.

- (2018). Disability, Health and Human Development. New York: Palgrave.

Molly Follette Story, M.S. (1998). Maximizing Usability: The Principles of Universal Design. Assistive Technology 10 (1), 4-12.

Oncins, E.; Fitzpatrick, D.; Altinier, A. (2020). Mapping The European Digital Accessibility Field: The IMPACT Project. In 9th International Conference on Software Development and Technologies for Enhancing Accessibility and Fighting Info-exclusion (DSAI 2020), December 0204, 2020, Online, Portugal. ACM, New York, NY, USA. https: //doi.org/10.1145/3439231.3440608

-. and Orero, P. (2020). No audience left behind, one App fits all: an integrated approach to accessibility services. JosTrans 34, 192-211. 
-.; Lopes, O.; Orero, P. and Serrano, J. (2013). All Together Now: A multilanguage and multi-system mobile application to make live performing arts accessible. JosTrans 20, 147-164.

Orero, P. and Matamala, A. (2013). Standarising Audio Description. Italian Journal of Special Education for Inclusion, 149-155.

- . and Tor-Carroggio, I. (2018). User requirements when designing learning e-content: interaction for all. In Evangelos Kapros and Maria Koutsombogera (Eds.), Designing for the User Experience in Learning Systems (pp. 105-121). Cham: Springer.

-.; Montagud ,M.; Mata, J.; Torres, E. and Matamala, A. (2020a). "Audio Subtitles or Spoken Subtitles: An ecological media accessibility service". In Dejica, D. \& C. Eugeni, A. Dejica-Cartis (eds) Translation Studies and Information Technology - New Pathways for Researchers, Teachers and Professionals. (pp. 155-167) Timișoara: Editura Politehnica, Translation Studies Series.

-, Delgado, C. and Matamala, A. (2020b). Easy to read standardisation. Some steps towards an international standard. In 9th International Conference on Software Development and Technologies for Enhancing Accessibility and Fighting Info-exclusion (DSAI 2020), December 0204, 2020, Online, Portugal. ACM, New York, NY, USA. https: //doi.org/ $10.1145 / 3439231.3440605$

Sanford, J. (2012). Universal design as a rehabilitation strategy. New York: Springer Publishing Company.

Puigdomènech, L., Orero, P., and Matamala, A. (2008). The Making of a Protocol for Opera Audio Description. In Pegenaute, L; DeCesaris, J.; Tricás, M. \& E. Bernal (Eds.) La traducción del futuro: mediación lingüística y cultural en el siglo XXI (pp.381-392). Barcelona: PPU.

Romero-Fresco, P. (2013) Accessible filmmaking: Joining the dots between audiovisual translation, accessibility and filmmaking. JosTrans 20, 201223.

Taylor, C. (2017) Getting Our House in Order: Moving from Diversity to Inclusion. The American Archivist: Spring/Summer 2017, 80 (1), 1929.1

WHO (2018) WHO.DAS 2.0. World Health Organization Disability Assessment Schedule 2.0. Retrieved from: https://www.who.int/classifications/icf/whodasii/en/ 